\title{
Comparison of floor and cage housing systems in terms of some welfare assessments in broiler
}

\author{
Nejla ÖZHAN ${ }^{1}$, Ülkü Gülcihan Şi̇MŞEK ${ }^{1}$, Mehtap ÖZÇELİK ${ }^{2}$ \\ ${ }^{1}$ Frrat University, Faculty of Veterinary Medicine, Animal Science Department; ${ }^{2}$ Frrat University, Health Services High School, \\ Biochemistry, Elazı $\breve{g}$, Turkey.
}

\begin{abstract}
Summary: This study was conducted to investigate simultaneously compare floor with cage housing systems in terms of some blood parameters, bone quality and $\mathrm{pH}$ level of Musculus pectoralis in broilers. The animal material of the study was consisted of a total of 30 broilers per housing system, having stable live weight, were selected on 32nd day of growing period. All broilers per system were choosen at six different flocks having 25.000 capacities. The chickens were slaughtered via beheading method and blood samples were collected into special tubes. The $\mathrm{pH}$ level of breast muscle was measured within ten minutes later following the slaughter. Bones were eviscerated from meat and analyzed in terms of physical properties and mineral levels. Serum glucose, verylow-density lipoprotein (VLDL cholesterol) and uric acid levels increased in broilers reared by cage housing systems $(\mathrm{P}<0.05)$. There were not any significant differences at serum total cholesterol, triglyceride, protein level and enzyme activities of alkaline phosphatase and creatine kinase $(\mathrm{P}>0.05)$. Ash ratios of tibio-tarsal and femora bones were lower in cage housing system $(\mathrm{P}<0.05)$. Dimensions and weights of tibia and femora bones were observed to have similar values between groups $(\mathrm{P}>0.05)$. $\mathrm{pH}$ levels of breast muscle was significantly higher in cage housing systems than floor system $(\mathrm{P}<0.01)$. Consequently, cage housing system was negatively affected on broiler's blood parameters, bone quality and $\mathrm{pH}$ level of breast muscle.

Keywords: Broiler, cage housing, floor housing, welfare.
\end{abstract}

\section{Yer ve kafes sistemlerinin etlik piliçlerde bazı refah parametreleri bakımından karşılaştırılması}

Özet: $\mathrm{Bu}$ araştırma, yer ve kafes sistemlerinde yetiştirilen etlik piliçlerin bazı biyokimyasal parametreler, kemik kalitesi ve Musculus pectoralis $\mathrm{pH}$ düzeyleri bakımından eş zamanlı olarak karşılaştırılması amacıyla yapıldı. Araştırmanın hayvan materyalini her yetiştirme sisteminden büyüme periyodunun 32. gününde seçilen sabit canlı ağırlıktaki 30 etlik piliç oluşturdu. Her sistemdeki piliçlerin tamamı 25.000 kapasiteli 6 farklı sürüden seçildi. Piliçler boyun uçurma yöntemi ile kesildi; kanları özel tüplere alındı. Kesimi takiben göğüs kasının pH'sı on dakika sonunda ölçüldü. Kemikler etlerinden soyuldu, fiziksel özellikleri ve mineral düzeyleri bakımından incelendi. Kafes sisteminde yetiştirilen etlik piliçlerde serum glukoz, çok düşük yoğunluklu lipoprotein (VLDL kolesterol) ve ürik asit düzeyi önemli ölçüde arttı $(\mathrm{P}<0.05)$. Serum total kolesterol, trigliserit ve protein düzeyleri ile alkalen fosfataz ve kreatin kinaz enzim aktivitelerinde önemli farklılık tespit edilmedi $(\mathrm{P}>0.05)$. Tibio-tarsal ve femur kemiklerinde kül düzeyi, kafes sisteminde yetiştirilen piliçlerde düşük bulundu $(\mathrm{P}<0.05)$. Tibia ve femur ağırlık, boy ve en değerleri gruplar arasında benzerdi $(\mathrm{P}>0.05)$. Kafes sisteminde gögüs kası $\mathrm{pH}$ düzeyi yer sisteminden önemli derecede yüksekti $(\mathrm{P}<0.01)$. Sonuç olarak, kafes sisteminin etlik piliçlerde kan parametreleri, kemik kalitesi ve göğüs kası pH’sını olumsuz etkilediği tespit edildi.

Anahtar sözcükler: Etlik piliç, kafes sistemi, refah, yer sistemi.

\section{Introduction}

Cage housing systems having different structural features for broiler chicken production have been current since 1960s. It was reported that the cages provide the most economic use of land, increasing efficiency per poultry house and decreasing production cost by making better use of fixed expenses $(14,26)$. However, they were not widely adopted because the broiler chickens are prone to some welfare and health problems because of lack of physical space, behavioral restrictions and environmental deficiencies (8). On the other hand, floor housing system is better for satisfaction of the bird's motivation for activity, dust bathing and other important behavioral activities than cage. Fouad et al. (10) reported that floorraised broiler chickens were more often seen walking, lying and pecking compared to those in cages. In contrast, caged broilers stood and drank significantly more often.

Increased levels of activity support bones and reduce bone deformities, whereas a lack of exercise can increase the incidence of leg abnormalities in broilers (2). Thorp and Duff (32) studied that the vascular morphology of the proximal femur, tibiotarsus and tarsometatarsus in broiler induced to physical activity for four periods of 15 minutes each day. It was found that the exercised birds had higher vasculature in 40 percent than the unexercised (control) birds. 
Fast-growing broiler breeds are quite sensitive to leg abnormalities (tibial dyschondroplasia, tarsal angulation, femoral epiphysiolysis), because, rapid growth of muscle tissue and high body weight are load on immature skeleton, joints and ligaments. The leg problems are important welfare and economic issue in broiler industry. Mortality and number of culls due to leg problems create significant part of total loss $(2,11,22)$.

It is well documented that changes in the blood parameters are good indicators of stress (32). Under stress condition, after the activation of the hypothalamicpituitary-adrenal cortical system and the subsequent secretion of corticosterone (CS), further metabolic alterations occur, which focus on glucose production and mobilization. Glucose is an essential energy source in vitals under this condition. CS promotes gluconeogenesis for endogenous glucose production from glycogen stores, or by synthesis in vivo from gluconeogenic precursors such as amino acids. On the other hand, enhanced lipolysis causes to increase in free fatty acid concentration and serum triglycerides, and prolonged stress rises in plasma cholesterol $(12,13)$. The levels of these parameters in blood are alterable depending on source and duration of the stress in poultry $(3,15)$.

Bone quality (mass, shape, internal architecture) is known to be influenced by the physical stresses (20). Bone ash, bone fracture resistance and bone densitometry are major parameters for estimating bone quality (17).

Meat quality may also be affected management practices, and increased production of epinephrine and glucocorticoids in animals exposed to preslaughter stressors can affect postmortem metabolism of meat. Generally, pale, soft and exudative meat (PSE) results from acute stress, and dark, firm and dry meat (DFD) results from chronic stress. It has been suggested that shortterm (acute) preslaughter stress results in an acceleration of muscle metabolism and this acceleration causes to a fast decline in muscle $\mathrm{pH}$ early postmortem while carcass temperatures are still high resulting in meat with pale color, poor water-holding capacity, and poor texture. Under chronic stress condition can cause depletion in muscle glycogen resulting in higher postmortem muscle $\mathrm{pH}$. Meat with this condition is dark in color, has a firm texture, and dry appearance or high water-holding capacity $(6,23)$. The main objectives of this study was therefore to determine a comparison of the blood parameters, bone quality and Musculus pectoralis $\mathrm{pH}$ level of broilers in cage and floor housing systems.

\section{Materials and Methods}

This research was conducted in poultry houses associated to an integrated facility located in Malatya following approval of Firat University Animal Ethics Committee (FUHADEK decree no: 08.11.2012/103).
Table 1. Composition of diets used in the study, $\%$. Tablo 1. Araştırmada kullanılan diyetin kompozisyonu, \%.

\begin{tabular}{lccc}
\hline Nutrients, \% & Starter & Grower & Finisher \\
\hline Dry material & 90.60 & 90.10 & 90.89 \\
Raw protein & 23.40 & 22.00 & 19.70 \\
Raw cellulose & 3.20 & 3.50 & 3.58 \\
Raw oil & 5.83 & 7.75 & 8.34 \\
Raw ash & 5.50 & 5.30 & 3.91 \\
Calcium*** & 1.00 & 0.93 & 0.85 \\
Usable & 0.51 & 0.51 & 0.44 \\
Phosphorus*** & & & \\
Methionine*** & 0.69 & 0.66 & 0.59 \\
Lysine*** & 1.44 & 1.27 & 1.11 \\
Threonine*** & 0.97 & 0.88 & 0.81 \\
ME, Kcal/kg*** & 3.011 & 3.176 & 3.225 \\
\hline
\end{tabular}

*Vitamin mix: Each $2.5 \mathrm{~kg}$ mix includes: Vitamin A 12.000.000 IU; Vitamin D3 2.000.000 IU; Vitamin E 35.000 $\mathrm{mg}$; Vitamin K3 $4.000 \mathrm{mg}$; Vitamin B1 $3.000 \mathrm{mg}$; Vitamin B2 $7.000 \mathrm{mg}$; Niacin $20.000 \mathrm{mg}$; Calcium D- pantothenate 10.000 mg; Vitamin B6 5.000 mg; Vitamin B12 15 mg; Folic Acid $1.000 \mathrm{mg}$; D-Biotin $45 \mathrm{mg}$; Vitamin C $50.000 \mathrm{mg}$; Choline Chloride $125.000 \mathrm{mg}$; Canthaxanthin $2.500 \mathrm{mg}$; Apo Carotenoids Acid Esters $500 \mathrm{mg}$.

**Mineral mix: each $1 \mathrm{~kg}$ mix includes: Manganese $80.000 \mathrm{mg}$; Iron 60.000 mg; Zinc 60.000 mg; Copper 5.000 mg; Cobalt 200 $\mathrm{mg}$; iodine $1.000 \mathrm{mg}$; selenium $150 \mathrm{mg}$.

***: Determined by calculation.

*Vitamin karışımı: Her 2.5 kg'lık karışımın içeriği: Vitamin A 12.000.000 IU; Vitamin D3 2.000.000 IU; Vitamin E 35.000 mg; Vitamin K3 4.000 mg; Vitamin B1 3.000 mg; Vitamin B2 $7.000 \mathrm{mg}$; Niasin $20.000 \mathrm{mg}$; Kalsiyum D- pantotenat 10.000 mg; Vitamin B6 $5.000 \mathrm{mg}$; Vitamin B12 $15 \mathrm{mg}$; Folik Asit $1.000 \mathrm{mg}$; D-Biotin $45 \mathrm{mg}$; Vitamin C $50.000 \mathrm{mg}$; Kolin Klorit $125.000 \mathrm{mg}$; Kantaksandin $2.500 \mathrm{mg}$; Apokarotenoids Asit Esterleri $500 \mathrm{mg}$.

**Mineral karışımı: Her 1 kg'lık karışımın içeriği: Manganez 80.000 mg; Demir 60.000 mg; Çinko 60.000 mg; Bakır 5.000 mg; Kobalt 200 mg; Iodin 1.000 mg; Selenyum 150 mg. ***: Hesapla tespit edilmiştir.

Chicks known as Ross-308 breed obtained from hatchery of the facility being animal materials of the study were placed in poultry houses randomly. Environmental conditions in two systems were organized according to the needs of broiler. Throughout the study, fresh water and feed produced at feed factory of facility in accordance with NRC standards were at disposal of broilers ad libitum. Composition of feed is presented in Table 1. To determine the examined parameters, six different flocks from each system having 25.000 broilers were simultaneously observed. A total of 30 broilers per system, five broilers per flock, having stable live weight and gender were selected on 32nd day of growing period. Broilers were slaughtered via beheading method and whole bloods of the chickens were drained into serum gel tubes in the course of slaughter. The blood was delivered to laboratory in cold chain. Blood samples were centrifuged at $4.000 \mathrm{rpm}$ for 4 minutes, and analyses 
were conducted at Firat University Hospital Central Laboratory. Blood analyzer (Simens Advia 2400, Japan) available in the laboratory was used to determine the glucose, total cholesterol, very-low-density lipoprotein cholesterol (VLDL), triglyceride, protein, uric acid, alkaline phosphatase and creatine kinase analyses of serums (Autoanalyser kit brand: Simens, 334678, USA). For physical analysis of bones, right tibio-tarsal bone and femur were used. The bones were initially weighed by precision balance featuring mg precision level, and then their sizes were measured by means of digital caliper (Tresna, USA). The bones chopped into small pieces with the help of a cutting tool for ash determination purpose were evaluated after incineration in a muffle furnace (Protherm, Turkey) at $600{ }^{\circ} \mathrm{C}$ for 7-8 hours (24). Determination of $\mathrm{pH}$ in meat is performed on the part of breast muscle (Musculus pectoralis) by use of meat $\mathrm{pH}$ meter manufactured by Hanna (HI 99163, Holland). pH measurement was performed within ten minutes after slaughter.

Chemical composition of food ingredients (dry matter, crude protein, ash and ether extract) were analyzed according to the AOAC (1) procedures and crude fiber was determined by the methods of Crampton and Maynard (4).

After test of normality, to determine the effects of housing system on examined parameters, all data were compared by independent samples t-test. Statistical analysis was performed with the help of SPSS 21 (29) software package. When the cases where differences among group averages were $\mathrm{P}<0.05$, they were considered statistically significant.

\section{Results}

Effects of floor and cage housing systems on blood parameters of broilers are given in Table 2. Serum glucose, VLDL cholesterol and uric acid $(\mathrm{P}<0.05)$ levels were found to be significantly higher in cage system compare with floor system. Serum cholesterol, triglyceride, protein levels and alkaline phosphatase and creatine kinase enzyme activities were statistically not significant $(\mathrm{P}>0.05)$.

Upon examination of data in Table 3, tibia and femora ash ratio was found to be significantly higher in floor system $(\mathrm{P}<0.05)$, however, weight, length and width of tibia and weight, length and width of femora

Table 2. Effect of floor and cage housing systems on some blood parameters in broilers.

Tablo 2. Yer ve kafes sistemlerinin etlik piliçlerde bazı kan parametreleri üzerine etkisi.

\begin{tabular}{lccc}
\hline Traits & FH & CH & P-statistical significance \\
\hline Glucose, $m g / d L$ & $220.16 \pm 4.97$ & $239.50 \pm 5.98$ & $*$ \\
Cholesterol, $m g / d L$ & $122.03 \pm 3.10$ & $118.87 \pm 2.49$ & NS \\
VLDL cholesterol, $m g / d L$ & $17.38 \pm 1.23$ & $20.71 \pm 1.35$ & $*$ \\
Triglyceride, $m g / d L$ & $76.30 \pm 5.21$ & $83.16 \pm 3.94$ & $\mathrm{NS}$ \\
Protein, $g / d L$ & $3.77 \pm 0.09$ & $3.86 \pm 0.10$ & $\mathrm{NS}$ \\
Uric acid, $m g / d L$ & $4.30 \pm 0.30$ & $5.36 \pm 0.30$ & $*$ \\
Alkaline phosphatase, $U / L$ & $3509.24 \pm 486.13$ & $4443.89 \pm 421.34$ & $\mathrm{NS}$ \\
Creatine kinase, $U / L$ & $10435.57 \pm 1594.34$ & $8880.14 \pm 651.74$ & $\mathrm{NS}$ \\
\hline
\end{tabular}

Data were given as mean \pm standard error. *: P $\leq 0.05$, FH: Floor housing, $\mathrm{CH}$ : Cage housing, VLDL cholesterol: Very-low-density lipoprotein cholesterol.

Veriler ort \pm standart hata olarak verilmiştir. *: $\mathrm{P} \leq 0.05$, FH: Yer sistemi, $\mathrm{CH}$ : Kafes sistemi, VLDL kolesterol: Çok düşük yoğunluklu lipoprotein kolesterol.

Table 3. Effect of floor and cage housing systems on some bone parameters in broilers.

Tablo 3. Yer ve kafes sistemlerinin etlik piliçlerde bazı kemik özellikleri üzerine etkisi.

\begin{tabular}{lccc}
\hline Traits & FH & CH & P-statistical significance \\
\hline Live weight, $g$ & $1967.19 \pm 19.67$ & $1942.11 \pm 21.13$ & NS \\
Tibia weight, $g$ & $13.89 \pm 0.42$ & $13.55 \pm 0.35$ & NS \\
Femora weight, $g$ & $10.03 \pm 0.32$ & $10.00 \pm 0.34$ & NS \\
Tibia length, $m m$ & $94.12 \pm 0.45$ & $93.75 \pm 0.50$ & NS \\
Femora length, $m m$ & $72.03 \pm 0.47$ & $71.89 \pm 0.45$ & NS \\
Tibia width, $m m$ & $7.60 \pm 0.16$ & $7.89 \pm 0.21$ & NS \\
Femora width, $m m$ & $8.26 \pm 0.15$ & $8.32 \pm 0.13$ & NS \\
Tibia ash, $\%$ & $15.81 \pm 0.35$ & $14.21 \pm 0.40$ & $*$ \\
Femora ash, $\%$ & $15.92 \pm 0.22$ & $15.24 \pm 0.27$ & $*$ \\
\hline
\end{tabular}

Data are given as mean \pm standard error, $*: \mathrm{P} \leq 0.05, \mathrm{FH}$ : Floor housing, $\mathrm{CH}$ : Cage housing.

Veriler ort \pm standart hata olarak verilmiştir. *: $\mathrm{P} \leq 0.05$, FH: Yer sistemi, $\mathrm{CH}$ : Kafes sistemi. 
were similar between groups in broilers having balanced live weight $(\mathrm{P}>0.05)$.

Upon examination of data in Table $4, M$. pectoralis $\mathrm{pH}$ level was $6.01 \pm 0.06$ in floor system and $6.31 \pm 0.07$ in cage system, the difference between groups was significant $(\mathrm{P}<0.01)$.

Table 4. Effect of floor and cage housing systems on $\mathrm{pH}$ in breast muscle in broiler.

Tablo 4. Yer ve kafes sistemlerinin etlik piliçlerde gögüs eti $\mathrm{pH}$ s1 üzerine etkisi.

\begin{tabular}{lccc}
\hline Traits & FH & $\mathrm{CH}$ & $\begin{array}{l}\text { P- statistical } \\
\text { significance }\end{array}$ \\
\hline & Hanna $($ HI 99163$)$ & \\
\hline $\begin{array}{l}\text { Pectoral muscle } \\
\text { pH level }\end{array}$ & $6.01 \pm 0.06$ & $6.31 \pm 0.07$ & $* *$ \\
\hline
\end{tabular}

Data are given as mean \pm standard error, ${ }^{* *}: \mathrm{P} \leq 0.01, \mathrm{FH}$ : Floor housing, $\mathrm{CH}$ : Cage housing.

Veriler ort \pm standart hata olarak verilmiştir. ${ }^{* *}$ : $\mathrm{P} \leq 0.01$, FH: Yer sistemi, CH: Kafes sistemi.

\section{Discussion and Conclusion}

This study showed that cage housing syetem increased serum glucose, VLDL cholesterol and uric acid levels (Table 2), probably associated with stress under cage condition. Under stress, rising CS promotes glucose production by mobilization and gluconeogenesis. Increasing serum glucose level of broilers in cage condition may be associated with effects of CS on carbohydrate metabolism (12). On the other hand, to production gluconeogenic substrates, CS induces the catabolism of structural protein to free amino acids. This action causes to production of nonprotein nitrogen and to decrease in the incorporation of glucose carbon into protein and increased uric acid excretion (34). An increased serum uric acid level of the present study is due to the reason of increased gluconeogenesis in caged chickens. Under stress condition, increasing CS also promotes cholesterol synthesis. VLDL is a transporter that it serves for long-range transport of endogenous triglycerides, phospholipids, cholesterol, and cholesteryl esters. These ingredients are utilized for VLDL assembly and secretion originates from multiple biosynthesis pathways. It was thought that VLDL may be secreted from the ingredients under stressed broiler in cage condition (30). In agree with these finding, Daneshyar et al. (7) demonstrated that glucose level in blood was noticeably high, protein level in blood was low and trigliserid, and cholesterol levels in blood did not change under chronic cold stress condition in broiler. Lin et al. (15) reported that broilers daily subject to $30 \mathrm{mg} / \mathrm{kg}$ corticosterone for 2 weeks long (long term treatment, chronic stress) caused the rise of plasma uric acid and ceruloplasmin level rose dramatically starting from the third day of treatment and broilers tried to defend themselves against severe damage of oxidative stress in this manner. Onbasilar and Aksoy (16) stressed that increasing blood glucose levels, due to the effect of glucocorticoids are described as an important indicator of stress conditions and added that higher stocking density in cage flooring system significantly increased serum glucose level in laying hens. There were no significant differences between two groups of the present study for serum cholesterol, triglyceride and protein levels. These findings were explainable with insufficient or balanced effects of housing system on the parameters. Serum creatine kinase and alkaline phosphatase activity are enzymes associated with muscle and bone tissues so that they may increase significantly under stress (11). Tang et al. (31) reported that serum creatine kinase (CK) activity rose dramatically in broilers exposed to acute heat stress at the time of slaughter and this parameter could be considered as an indicator of stress. Rajman et al. (19) observed that controlled and feed restricted groups in broilers under restriction of feed during growing period; plasma glucose level was similar, alkaline phosphatase level was low in feed restricted group whilst creatine kinase level was high for the group fed ad libitum. The researchers related these findings with negative impact of fast-growing on health and welfare of broilers. Different from these researches, serum creatine kinase and alkaline phosphatase activity was found to be similar between cage and floor housing groups of the present study. These findings can be associated similar effects of housing systems on these enzyme activities.

Deficiency in activity is associated with gait and skeletal disorders in poultry (20). In the previous researches, it was found that broiler chickens reared in cage had a greater prevalence of gait problems, impaired walking ability and leg abnormalities than those reared on the floor systems $(26,33)$. On the other hand, there was insufficient evidence to support the original hypothesis that increased activity promotes good leg health in broiler. Some researches reported that broiler chickens do not exercise enough or do not perform the higher impact activities required to affect bone quality because of their genetic capability (25). Conversely, suppressed activity can affect the bone structure to cause physical stress (32). Overproduction of ROS induces an imbalance between pro-oxidants and antioxidants in cells and tissues resulting in oxidative stress (15, 27). Malondialdehyde (MDA) is end product of lipid peroxidation and an important indicator of stress in poultry (27). Simsek et al. (28) reported that cage housing system caused oxidative stress associated with increasing serum MDA level in broiler. The ROS may play an important role in bone formation in part by inhibiting osteoblast generation from osteoprogenitors cells. In addition, oxidative stress is involved in 
apoptosis of osteoblasts and osteocytes and in osteoclastogenesis and therefore also in bone resorption which leads to a fragile skeleton and increased risk of fractures $(9,18)$. Physical exercise can lead to an increase in some antioxidants in bone as well as cartilage resulting in good bone formation (22). In agree with these researches, upon examination of data in Table 3, intergroup differences were not found as statistically significant in terms of tibia and femur physical traits (weight, length and width). Decreasing bone ash ratio in the cage housing system of present study may be associated with both suppressed activity and oxidative stress in cage condition. Tolon and Yalcin (33) reported that humerus weight and ash content were affected by cage rearing whereas tibia weight and ash were not different and also birds reared in plastic mesh floor in cages had shorter tibia and humeri than birds reared in floor pens.

When $\mathrm{pH}$ value in Musculus pectoralis in Table 4 was examined, it can be seen that significantly higher $\mathrm{pH}$ was obtained in broiler reared cage system. Even though this high ratio was the range of DFD meat values $(\mathrm{pH}>6.2)$ defined by Ristić and Klaus (21). Dadgar et al. (5) reported that transportation of birds at exposure temperatures below $0^{\circ} \mathrm{C}$ for 3 to $4 \mathrm{~h}$ before slaughter resulted in breast meat with a darker color, higher $\mathrm{pH}$ and higher water-binding capacity, causing an increase in the incidence of dark, firm and dry (DFD) breast meat. In the another study, Dadgar et al. (6) found that $\mathrm{pH}$ value in Musculus pectoralis of broilers exposed to cold stress at the age of slaughter, depending on degree of cold level, rose significantly compared to the control group. Unlike from our findings, Lacin et al. (14) reported that the $\mathrm{pH}$ values of breast meat in floor breeding and cage breeding groups were determined as 6.14 and 5.95, respectively. The broiler reared at floor breeding had significantly higher $\mathrm{pH}$ value.

In conclusion, inspecting of the present study results, it can be said that cage housing system causes chronic stress on broiler by creating higher glucose, VLDL and uric acid concentrations of serum, lower bone ash ratios and higher $\mathrm{pH}$ of breast meat. Finally, rearing broilers in a conventional litter-based house was superior to a nonlitter cage-based housing system in terms of good animal welfare.

\section{Acknowledgement}

I would like to thank FUBAP (VF.13.04) for financially supporting this study, owner of commercial company, all flock owners and flock employees.

\section{References}

1. AOAC (2000): Official Methods of Analysis Association of AOAC International. 17th ed., (AOAC International Maryland).
2. Bizeray D, Leterrier C, Constantin P, et al. (2000): Early locomotor behaviour in genetic stocks of chickens with different growth rates. Appl Anim Behav, 68, 231242.

3. Ciftci M, Simsek UG, Azman MA, et al. (2013): The effects of dietary rosemary (Rosmarinus officinalis L.) oil supplementation on performance, carcass traits and some blood parameters of Japanese quail under heat stressed condition. Kafkas Univ Vet Fak Derg, 19, 595-599.

4. Crampton EW, Maynard LA (1983): The relation of cellulose and lignin content to nutritive value of animal feeds. J Nutr, 15, 383-395.

5. Dadgar S, Lee ES, Leer TLV, et al. (2010): Effect of microclimate temperature during transportation of broiler chickens on quality of the pectoralis major muscle. Poult Sci, 89, 1033-1041.

6. Dadgar S, Lee ES, Leer TLV, et al. (2011): Effect of acute cold exposure, age, sex, and lairage on broiler breast meat quality. Poult Sci, 90, 444-457.

7. Daneshyar M, Kermanshahi H, Golian A (2009): Changes of biochemical parameters and enzyme activities in broiler chickens with cold-induced ascites. Poult Sci, 88, 106-110.

8. Duncan IJH (2001): The pros and cons of cages. World Poult Sci J, 57, 381-390.

9. Filaire E, Toumib H (2012): Reactive oxygen species and exercise on bone metabolism: Friend or enemy? Joint Bone Spine, 79, 341-346.

10. Fouad MA, Razek AHA, Badawy SM (2008): Broilers welfare and economics under two management alternatives on commercial scale. Int J Poul Sci, 7, 1167-1173.

11. Hocking PM, Maxwell MH, Robertson GW, et al. (2001): Welfare assessment of modified rearing programmes for broiler breeders. Br Poultry Sci, 42, 424-432.

12. Johnson JS (2014): Heat stress alters animal physiology and post-absorptive metabolism during pre-and postnatal development. Graduate Theses and Dissertations. Paper 13982.

13. Kissebah AH (1974): 'Stress' Hormones and Lipid Metabolism. Proc R Soc Med, 67, 665-667.

14. Lacin E, Coban O, Aksu MU, et al. (2013): The effects of different breeding methods on fattening performance and parameters related to slaughter, carcass and some meat quality in broiler chickens. Kafkas Univ Vet Fak Derg, 19, 283-289.

15. Lin H, Decuyperea E, Buyse J (2004): Oxidative stress induced by corticosterone administration in broiler chickens (Gallus gallus domesticus) 1. Chronic exposure. Biochem Physiol B-Biochem Mol Biol, 139, 737-744.

16. Onbasilar EE, Aksoy FT (2005): Stress parameters and immune response of layers under different cage floor and density conditions. Livest Prod Sci, 95, 255-263.

17. Orban JI, Roland DA, Bryant MM, et al. (1993): Factors influencing bone mineral content, density, breaking strength, and ash as response criteria for assessing bone quality in chickens. Poult Sci, 72, 437-446.

18. Ostman B, Michaëlsson K, Byberg L, et al. (2009): Oxidative stress and bone mineral density in elderly men: Antioxidant activity of alpha-tocopherol. Free Radical Bio Med, 47, 668-673.

19. Rajman M, Juráni M, Lamošová D, et al. (2006): The effects of feed restriction on plasma biochemistry in 
growing meat type chickens (Gallus gallus). Comp Biochem Physiol A: Physiol, 145, 363-371.

20. Rath NC, Huff GR, Huff WE, et al. (2000): Factors regulating bone maturity and strength in poultry. Poult Sci, 79, 1024-1032.

21. Ristić M, Klaus D (2010): The meaning of pH-value for the meat quality of broilers - Influence of breed lines. Tehnol Mesa, 51, 120-123.

22. Rizk SW, Stake PE, Simmons RW (1980): Curled toes and perosis-like leg abnormalities in cage reared broilers. Poult Sci, 59, 308-15.

23. Sams AR (1999): Meat quality during processing. Poult Sci, 78, 798-803.

24. Sari M, Cerci IH (1993): Animal feeds and nutritional diseases. Chemical analysis of feeds. Elazı $\breve{g}$-Tolga-Ofset, p: 266-279.

25. Sherlock L, Demmers TGM, Goodship AE, et al. (2010): The relationship between physical activity and leg health in the broiler chicken. Br Poult Sci, 51, 22-30.

26. Shields S, Greger M (2013): Animal welfare and food safety aspects of confining broiler chickens to cages. Animals, 3, 386-400.

27. Simsek UG, Ciftci M, Dogan G, et al. (2013): Antioxidant activity of cinnamon bark oil (Cinnamomum zeylanicum L.) in Japanese quails under thermo neutral and heat stressed conditions. Kafkas Univ Vet Fak Derg, 19, 889-894.

28. Simsek UG, Erisir M, Ciftci M, et al. (2014): Effects of cage and floor housing systems on fattening performance, oxidative stress and carcass defects in broiler chicken. Kafkas Univ Vet Fak Derg, 20, 727-733.
29. Statistical Packages for the Social Sciences (SPSS 21) (2012): Licensed materials property of IBM corporation (C) copyright IBM corporation and other(s). 1989-2012; International.

30. Sundaram M, Yao Z (2010): Recent progress in understanding protein and lipid factors affecting hepatic VLDL assembly and secretion. Nutr Metab, 7, 35.

31. Tang S, Yu J, Zhang M, et al. (2013): Effects of different heat stress periods on various blood and meat quality parameters in young Arbor Acer broiler chickens. Can J Anim Sci, 93, 453-460.

32. Thorp BH, Duff SRI (1988): Effect of exercise on the vascular pattern in the bone extremities of broiler fowl. Res Vet Sci, 45, 72-77.

33. Tolon B, Yalcin S (1997): Bone characteristics and body weight of broilers in different husbandry systems. Br Poult Sci, 38, 132-5.

34. Virden WS, Kidd MT (2009): Physiological stress in broilers: Ramifications on nutrient digestibility and responses. J Appl Poult Res, 18, 338-347.

Geliş tarihi: 14.04.2015 / Kabul tarihi: 09.10.2015
Address for correspondence:
Assoc. Prof. Dr. Ülkü Gülcihan Şimşek
University of Firat, Faculty of Veterinary Medicine,
Department of Animal Science,
23119 - Elazı̆̆, Turkey.
e-mail: gsimsek@firat.edu.tr 